\title{
ANALISIS KESULITAN KEMAMPUAN PEMECAHAN MASALAH MATEMATIS DITINJAU DARI KEMAMPUAN DISPOSISI MATEMATIS SISWA
}

\author{
Sofie Dinia ${ }^{1}$, Astri Yuliani Nurhafifah ${ }^{2}$, Mayasari $^{3}$, Siti Patimah ${ }^{4}$, Wahyu Hidayat ${ }^{5}$ \\ Institut Keguruan dan Ilmu Pendidikan Siliwangi, Jl. Terusan Jenderal Sudirman, \\ Cimahi, Jawa Barat, Indonesia ${ }^{1,2,3,4,5}$
}

Email: wahyu@ikipsiliwangi.ac.id

\begin{abstract}
The purpose of this study was to study and analyze students' problems in problem-solving skills seen from their mathematical disposition level of the students on 12th grade class of SMA IT Fithrah Insani. Method of this study is descriptive- qualitative research. From 35 students, there were three students taken as samples, consisting of a student with high disposition mathematical ability (T), a student with medium disposition mathematical ability (S), and a student with low disposition mathematical ability (R). The result of the study shows that there is a difference in the average score of students in each level of the mathematical disposition towards the conclusion of the students' mathematical problem-solving ability test (ANOVA Test-One way). Following up on these differences, researchers identified student achievement and misconceptions on each mathematical problem-solving indicators. The results of the study show that all the student with high and medium disposition mathematical ability could not fulfill the indicators of the ability of mathematical problem solving, such as (1) understand the problem, (2) recheck the answer while all the student with low disposition mathematical ability could not fulfill all indicator of the ability of mathematical problem solving.
\end{abstract}

Keywords: Mathematical problem-solving; Mathematical Disposition.

\section{PENDAHULUAN}

Rendahnya prestasi belajar siswa di Indonesia merupakan masalah yang sukar untuk diatasi dan diselesaikan. Terutama dalam mata pelajaran matematika yang sebagian besar siswa menganggap bahwa belajar matematika itu sulit. Begitu pun juga dengan kemampuan pemecahan masalah dan disposisi matematis yang dalam era ini merupakan dua hal yang penting dalam pendidikan matematika yang juga merupakan masalah yang menjadi hambatan dalam pembelajaran matematika di Indonesia (Hidayat \& Sariningsih, 2018). Oleh karena itu, kemampuan pemecahan masalah dan disposisi matematis siswa perlu dikembangkan sejak usia dini. Kemampuan pemecahan masalah 
merupakan salah satu kemampuan yang penting untuk dikembangkan dan dimiliki siswa. Dengan demikian bahwa kemampuan pemecahan masalah harus dimiliki oleh siswa untuk menyelesaikan persoalan persoalan matematika untuk mengatasi kesulitan yang ditemui untuk mencapai suatu tujuan yang diinginkan (Hidayat \& Sariningsih, 2018; Sumartini 2018).

Hasil studi TIMSS Tahun 2011 menyatakan bahwa kemampuan matematis siswa Indonesia berada pada peringkat 38 dari 42 negara dengan skor rata-rata 386 dimana rata-rata TIMSS berkisar di skor 500. Hasil studi TIMSS tersebut memberikan gambaran bahwa siswa Indonesia memiliki kemampuan rendah dalam menjawab soalsoal yang berstandar internasional terutama pada kemampuan pemecahan masalah matematis. Kelemahan ini tidak lain timbul disebabkan karena dalam pembelajaran matematika siswa belum terbiasa dan terlatih untuk menyelesaikan soal non rutin yang menantang agar siswa berpikir lebih kritis. Menurut Sabandar (2010) di dalam kelas diperlukan situasi dan masalah-masalah yang menantang namun menarik sehingga dapat menimbulkan rasa ingin tahu yang sekaligus dapat memicu siswa untuk mau berpikir lebih kritis.

Data yang diperoleh dari TIMSS, kelemahan siswa-siswi Indonesia terletak pada bagian menyelesaikan soal-soal non rutin yang memerlukan pembuktian, pemecahan masalah yang memerlukan penalaran matematika, menemukan generalisasi, dan menemukan hubungan antara data-data atau fakta yang diberikan. Kelemahankelemahan ini tidak lain timbul disebabkan karena dalam pembelajaran matematika siswa belum terbiasa dan terlatih untuk menyelesaikan soal non rutin yang menantang agar siswa berpikir lebih kritis.

Selain kurang merangsang siswa berpikir, pelaksanaan pembelajaran matematika juga cenderung hanya mengacu pada satu buku teks dengan langkah-langkah pembelajaran konvensional yaitu: menyajikan materi, memberikan contoh soal, meminta siswa mengerjakan latihan yang terdapat pada buku teks, dan kemudian membahas bersama siswa. Pembelajaran lebih menghasilkan siswa yang hanya pandai mengingat saja dan melakukan hal-hal yang sudah biasa atau rutin sehingga kemampuan berpikir siswa kurang berkembang dalam memecahkan masalah matematis. Maka dari itu dapat disimpulkan kemampuan pemecahan masalah matematis masih sangat rendah. 
Belajar matematika tidak hanya sebatas mengembangkan ranah kognitif semata. Pembelajaran seyogyanya memuat dan mengembangkan aspek afektif siswa merupakan komponen kunci untuk kesuksesannya dalam mempelajari matematika (Haryono \& Tanujaya, 2018; Rahmasantika \& Prahmana, 2018). Aspek afektif tersebut dalam kata lain merupakan Disposisi Matematis. Kurangnya sifat afektif tersebut dinilai dapat menghambat kemampuan siswa untuk memecahkan masalah yang berkaitan dengan matematika atau bidang lainnya. Sedangakan aspek-aspek afektif tersebut dalam era ini dinilai sebagai sesuatu hal yang sangat menunjang siswa dalam pemecahan suatu masalah. Aspek afektif tersebut dalam kata lain merupakan Disposisi Matematis.

Disposisi menurut Sumarmo et al. (2012) adalah keinginan, kesadaran, dan dedikasi yang kuat pada diri siswa untuk belajar matematika dan melaksanakan berbagai kegiatan matematika. Siswa harus mempunyai keinginan untuk belajar matematika agar memudahkan mereka dalam kegiatan pembelajaran. Selanjutnya Wardanny (2017) mengemukakan beberapa indikator disposisi matematis diantarannya adalah: rasa percaya diri, ekspektasi dan metakognisi, kesungguhan dan perhatian serius dalam belajar matematika, kegigihan dalam menghadapi dan menyelesaikan masalah, rasa ingin tahu yang tinggi, serta kemampuan berbagi pendapat/informasi dengan orang lain. Dari pernyataan tersebut mengindikasikan bahwa disposisi matematis merupakan faktor utama atau faktor penentu dalam menentukan kesuksesan belajar matematika siswa (Akbar et al., 2018; Choridah, 2013; Ikhsan, \& Rizal, 2014; Sugilar, 2013).

Dalam rangka untuk mengetahui kelemahan siswa pada kemampuan pemecahan masalah, maka peneliti melakukan suatu analisis kesulitan siswa dalam kemampuan pemecahan masalah yang ditinjau dari kemampuan disposisi matematis. Dengan demikian, tujuan penelitian ini adalah untuk mengetahui dan menganalisis secara mendalam tentang kesulitan siswa dalam kemampuan pemecahan masalah dilihat dari tingkat disposisi matematisnya.

\section{METODE PENELITIAN}

Metode penelitian yang digunakan adalah metode deskriptif kualitatif dengan subjek penelitian yaitu 34 siswa kelas XII SMAIT Fitrah Insani yang kemudian dikelompokkan ke dalam tiga kategori yang didasarkan pada hasil pengisian angket oleh siswa. Ketiga kategori tersebut yaitu siswa dengan kemampuan disposisi matematis tinggi (T), siswa dengan kemampuan disposisi matematis sedang $(\mathrm{S})$, dan siswa dengan 
kemampuan disposisi matematis rendah (R). Pengelompokkan ketiga kategori tersebut mengacu pada skala penilaian menurut Azwar (2013) yaitu:

Tabel 1. Kriteria Kategori Sikap Siswa terhadap Matematika

\begin{tabular}{cc}
\hline Skor & Kategori \\
\hline Skor $<\bar{x}-\frac{1}{2} s$ & Rendah \\
$\bar{x}-\frac{1}{2} s \leq s k o r \leq \bar{x}+\frac{1}{2} s$ & Sedang \\
Skor $>\bar{x}+\frac{1}{2} s$ & Tinggi \\
\hline
\end{tabular}

Instrumen yang digunakan pada penelitian ini adalah instrumen angket dan tes. Instrumen angket digunakan untuk mengetahui kemampuan disposisi matematis siswa dalam mengikuti proses pembelajaran matematika, sedangkan instrumen tes digunakan untuk mendapatkan hasil pekerjaan siswa dalam menyelesaikan soal kemampuan pemecahan masalah matematis yang kemudian ditinjau dari hasil tes kemampuan disposisi matematis siswa. Hasil tes dianalisis menggunakan analisis data kualitatif yang didasarkan pada indikator kemampuan pemecahan masalah. Selain itu untuk melihat perbedaan nilai rata rata dari hasil belajar siswa di masing-masing tingkat disposisi matematis peneliti melakukan uji statistik dengan menggunakan Uji Anova (One Way) dengan berbatuan aplikasi Minitab 17.0.

\section{HASIL DAN PEMBAHASAN}

Penelitian ini bertujuan untuk menganalisis kesulitan siswa dalam kemampuan pemecahan masalah dilihat dari tingkat disposisi matematisnya. Soal uraian yang menjadi alat penelitian terdiri dari 5 soal materi Sistem Pertidaksamaan Dua Variabel dengan indikator pemecahan masalah matematis pada soal-soal tersebut. Berikut adalah hasil kerja siswa pada soal pemecahan masalah matematis yang ditinjau dari dispoisisi matematis siswa. 
Tabel 2. Pencapaian Indikator Kemampuan Pemecahan Masalah Ditinjau dari Kemampuan Disposisi Matematis Siswa

\begin{tabular}{ccccccc}
\hline NO. & \multicolumn{2}{c}{ TINGGI (T) } & \multicolumn{2}{c}{ SEDANG (S) } & \multicolumn{2}{c}{ RENDAH (R) } \\
\cline { 2 - 7 } SOAL & BENAR & SALAH & BENAR & SALAH & BENAR & SALAH \\
\hline Soal 1 & 10 & 1 & 7 & 4 & 10 & 2 \\
Soal 2 & 5 & 6 & 5 & 6 & 5 & 7 \\
Soal 3 & 4 & 7 & 1 & 10 & 4 & 8 \\
Soal 4 & 5 & 6 & 3 & 8 & 0 & 12 \\
Soal 5 & 8 & 3 & 6 & 5 & 11 & 1 \\
\hline
\end{tabular}

Hasil tes instrumen angket menunjukkan bahwa terdapat sebanyak 11 siswa memiliki tingkat kemampuan disposisi matematis tinggi (T), 11 siswa memiliki tingkat kemampuan disposisi matematis sedang (S), dan 12 siswa memiliki tingkat kemampuan disposisi matematis rendah $(\mathrm{R})$.

Pada penelitian ini peneliti melakukan uji statistik dengan menggunakan Uji Anova (One Way) dengan berbantuan aplikasi Minitab 17.0. Hal ini dilakukan untuk melihat apakah terdapat perbedaan nilai rata rata dari hasil belajar siswa di masingmasing tingkat disposisi matematis dengan taraf signifikansi sebesar 5\%, sedangkan hipotesis yang diuji adalah:

- Ho: Disposisi Matematis Tinggi $(\mathrm{T})=$ Disposisi matematis Sedang $(\mathrm{S})=$ Disposisi Matematis Rendah $(\mathrm{R}) \approx$ tidak ada perbedaan nilai rata-rata siswa disposisi tinggi $(\mathrm{T})$, sedang $(\mathrm{S})$ dan rendah $(\mathrm{R})$.

- Ha: Disposisi Matematis Tinggi $(\mathrm{T}) \neq$ Disposisi matematis Sedang $(\mathrm{S}) \neq$ Disposisi Matematis Rendah $(\mathrm{R}) \approx$ terdapat perbedaan nilai rata-rata siswa disposisi tinggi $(\mathrm{T})$, sedang $(\mathrm{S})$ dan rendah $(\mathrm{R})$.

Hasi dari uji Anova adalah sebagai berikut:

Tabel 3. Analysis of Variance

\begin{tabular}{cccccc}
\hline Source & DF & Adj SS & Adj MS & F-Value & P-Value \\
\hline Factor & 2 & 1233.3 & 616.63 & 59.19 & 0.000 \\
Error & 31 & 323.0 & 10.42 & & \\
\hline Total & 33 & 1556.2 & & & \\
\hline
\end{tabular}

Berdasarkan hasil analisis pada Tabel 3, diperoleh P-Value $\leq \alpha$. Dengan demikian 
maka Ho ditolak, sehingga dapat dinyatakan bahwa terdapat perbedaan nilai rata-rata di masing-masing tingkat disposisi matematis siswa. Penolakan Ho menyebabkan pengujian perlu dilanjutkan untuk mencari perbedaan antar masing-masing tingkat disposisi. Hasil pengujian untuk mencari perbedaan pada masing-masing tingkat disposisi disajikan pada Tabel 4.

Tabel 4. Tukey Simultaneous Tests for Differences of Means

\begin{tabular}{ccccccc}
\hline \multicolumn{1}{c}{ Difference of } & Difference & SE of & & 95\% CI & \multicolumn{2}{c}{ Adjusted } \\
\cline { 1 - 2 } \cline { 6 - 7 } \multicolumn{1}{c}{ Levels } & Means & Difference & & T-Value & P-Value \\
\hline Sedang vs Tinggi & -8.64 & 1.38 & $(-12.02,-5.25)$ & -6.27 & 0.000 \\
Tendah vs Tinggi & -14.61 & 1.35 & $(-17.93,-11.30)$ & -10.85 & 0.000 \\
Rendah vs Sedang & -5.98 & 1.35 & $(-9.29,-2.66)$ & -4.44 & 0.000 \\
\hline
\end{tabular}

Berdasarkan Tabel 4, diperoleh nilai P-Value masing-masing tingkat disposisi matematis lebih kecil dari nilai taraf signifikansi ( $\mathrm{P}$-Value $\leq \alpha)$, sehingga Ho ditolak untuk setiap masing-masing tingkat disposisi matematis. Hal ini menyatakan bahwa siswa dengan disposisi matematis tinggi (T), sedang (S), dan rendah (R) masing-masing memiliki nilai rata-rata yang saling berbeda.

Berdasarkan hasil pengujian yang telah dilakukan, diperoleh bahwa setiap tingkatan disposisi matematis siswa memiliki nilai rata-rata yang berbeda terhadap hasil tes dengan indikator kemampuan pemecahan masalah. Oleh karena itu peneliti melakukan identifikasi ketercapaian dan identifikasi miskonsepsi siswa pada setiap indikator kemampuan pemecahan masalah matematis untuk mengetahui penyebab perbedaan nilai rata-rata pada hasil tes siswa.

\section{Identifikasi Ketercapaian Siswa pada Indikator Pemecahan Masalah Matematis yang Ditinjau dari Kemampuan Disposisi Matematis Siswa.}

Pada penelitian ini masing-masing soal memuat indikator kemampuan pemecahan masalah matematis yaitu memahami masalah, membuat rencana, melakukan perhitungan sesuai rencana, dan mengecek kembali hasil yang diperoleh. Oleh karena itu, identifikasi ketercapaian siswa pada kemampuan pemecahan masalah yang ditinjau dari kemampuan disposisi matematis dilihat dari setiap instrumen soal yang diberikan.

Pada soal nomor pertama, 10 siswa yang memiliki kemampuan disposisi matematis tinggi (T) mampu menjawab soal nomor pertama dengan benar dan 1 siswa menjawab salah. Pada siswa berdisposisi matematis sedang (S) 7 siswa dapat menjawab 
dengan benar dan 4 siswa menjawab salah. Sedangkan pada siswa dengan disposisi matematis rendah (R), 10 siswa menjawab dengan benar dan 2 siswa menjawab dengan salah.

Hal ini membuktikan bahwa siswa dengan disposisi matematis tinggi dan siswa dengan disposisi matematis rendah hampir seluruhnya dapat mengerjakan dengan benar soal nomor pertama. Sedangkan siswa dengan disposisi matematis sedang hanya 7 dari 11 siswa yang mampu menjawab dengan benar soal nomor pertama.

Pada soal nomor dua, 5 siswa dengan kemampuan disposisi matematis tinggi (T) dapat menjawab dengan benar dan 6 siswa menjawab salah. Begitupun pada siswa dengan disposisi matematis sedang (S), 5 siswa dapat menjawab dengan benar dan 6 siswa menajwab salah. Sedangakan pada siswa dengan disposisi matematis rendah (R), 5 siswa menjawab dengan benar dan 7 siswa menjawab salah. Hal ini menggambarkan bahwa hanya kurang dari setengah siswa pada masing-masing tingkat disposisi matematis yang dapat menjawab soal nomor dua dengan benar.

Pada soal nomor tiga, sebanyak 4 siswa dengan disposisi matematis tinggi (T) dapat menjawab soal dengan benar dan 7 siswa menjawab salah. Pada siswa dengan disposisi matematis sedang (S) 1 siswa menjawab dengan benar dan 10 siswa menjawab salah. Sedangkan siswa dengan disposisi matematis rendah (R) 4 siswa menjawab dengan benar dan 8 siswa menjawab dengan salah. Dari hasil tersebut, terlihat bahwa siswa dengan tingkat disposisi sedang (S) kesulitan dalam mengerjakan soal nomor tiga, hanya 1 dari 11 siswa yang menjawab dengan benar.

Pada soal nomor empat, sebanyak 5 siswa dengan tingkat disposisi tinggi (T) dapat menjawab dengan benar dan 6 siswa menjawab salah. Pada siswa dengan tingkat disposisi sedang (S) 3 siswa menjawab dengan benar dan 8 siswa menjawab salah. Sedangkan pada tingkat disposisi rendah (R) tidak ada siswa yang menjawab dengan benar soal nomor empat. Hal ini menunjukkan bahwa siswa dengan tingkat disposisi rendah $(\mathrm{R})$ tidak dapat memecahkan masalah pada soal nomor empat.

Pada soal nomor lima, sebanyak 8 siswa dengan disposisi matematis tinggi (T) dapat menjawab soal dengan benar dan 3 siswa menjawab salah. Pada siswa dengan disposisi sedang (S) 6 siswa mampu menjawab dengan benar dan 5 siswa menjawab salah. Sedangkan pada siswa dengan disposisi rendah (R) 11 siswa menjawab dengan benar dan 1 siswa menjawab salah. Dengan demikian siswa dengan tingkat disposisi 
rendah $(\mathrm{R})$ adalah siswa yang paling banyak menjawab dengan benar soal nomor lima.

Dari kelima soal di atas yang memuat indikator kemampuan pemecahan masalah matematis terlihat bahwa soal nomor 2 adalah soal yang secara merata dapat dipecahkan oleh setiap tingkatan dispoisisi matematis siswa. Pada tingkat disposisi matematis tinggi (T) siswa paling banyak menjawab dengan benar soal pertama, sedangkan pada tingkat disposisi matematis sedang (S) siswa paling banyak menjawab dengan benar soal nomor lima. Sedangkan pada tingkat disposisi matematis rendah (R) siswa paling banyak menjawab soal dengan benar pada soal nomor lima.

\section{Identifikasi Miskonsepsi Siswa pada Indikator Pemecahan Masalah Matematis}

Selain identifikasi ketercapaian pada setiap indikator pemecahan masalah, peneliti mengidentifikasi miskonsepsi siswa pada setiap tingkatan disposisi matematis dalam menyelesaikan soal kemampuan pemecahan masalah matematis. Identifikasi miskonsepsi berupa pembahasan hasil kerja siswa pada soal yang paling banyak dijawab salah oleh siswa pada setiap tingkatan disposisi matematis. Pada tingkat disposisi matematis tinggi (T) dan tingkat disposisi matematis sedang (S) soal nomor 3 adalah soal yang paling banyak dijawab salah oleh siswa pada tingkat disposisi tersebut. Sedangkan pada tingkat disposisi rendah (R) soal nomor empat adalah soal yang paling banyak dijawab salah oleh siswa dengan tingkat disposisi matematis rendah (R). Berikut hasil identifikasi miskonsepsi siswa pada indikator pemecahan masalah berdasarkan tingkatan disposisi matematis siswa.

\section{Soal nomor 3}

Selisih umur ayah dan anak perempuannya adalah 26 tahun, sedangkan 5 tahun yang lalu jumlah umur keduanya 34 tahun. Berapakah umur ayah dan anak perempuannya 2 tahun yang akan datang?

\section{Jawaban siswa:}

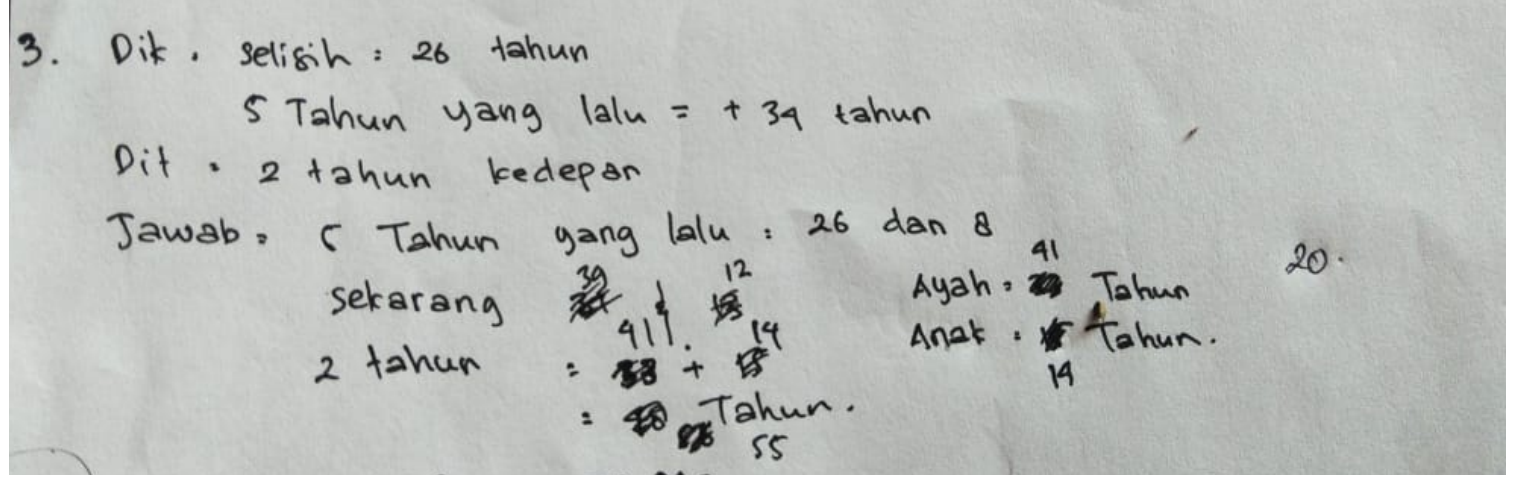




\section{Gambar 1. Jawaban Siswa yang Berdisposisi Matematis Tinggi}

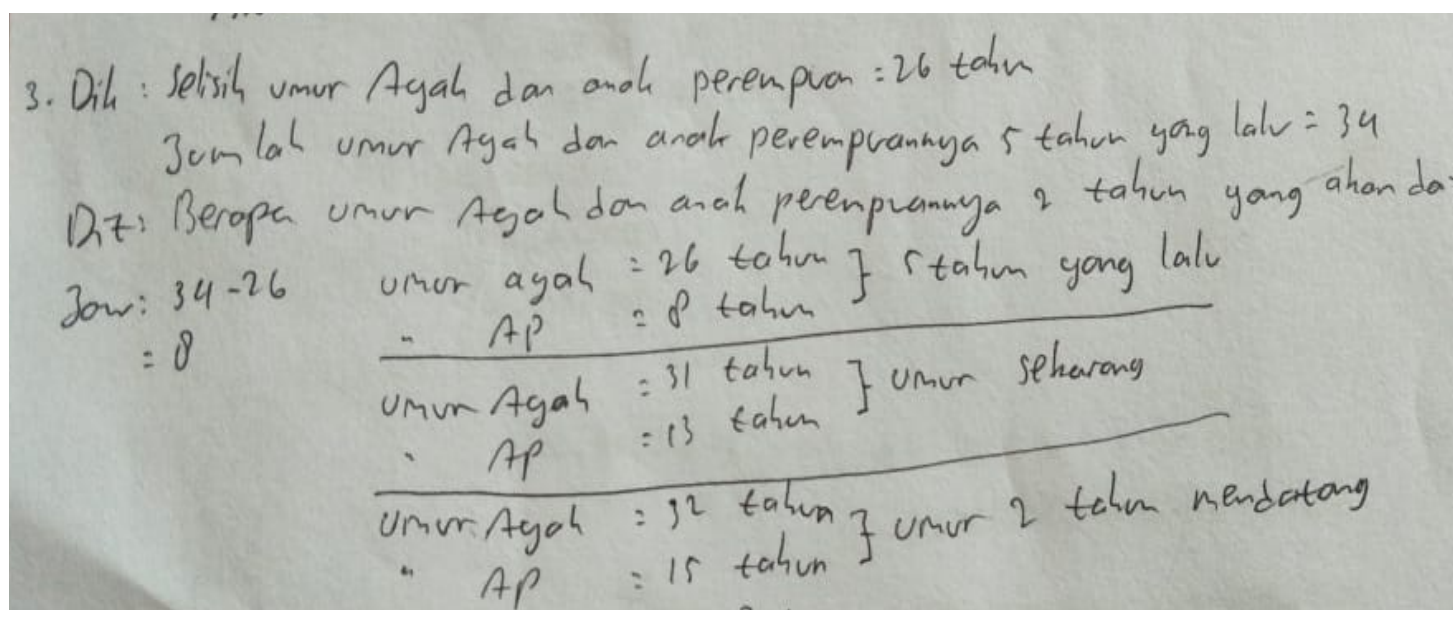

Gambar 2. Jawaban Siswa yang Berdisposisi Matematis Sedang

Berdasarkan Gambar 1 dan Gambar 2, terlihat bahwa dalam menyelesaikannya, siswa yang berdisposisi matematis tinggi $(\mathrm{T})$ dan siswa yang berdisposisi matematis sedang (S) mereka telah merencanakan dan melaksanakan perhitungan, namum perencanaan dan perhitungan yang dibuat menjadi kurang tepat karena mereka kurang dapat memahami soal, mereka juga tidak mengecek ulang hasil jawabannya. Dengan demikian dapat disimpulkan bahwa siswa dengan kemampuan disposisi matematis tinggi (T) dan sedang (S) tidak dapat memenuhi indikator memahami soal dan mengecek kembali hasil jawaban (Akbar et al., 2018; Choridah, 2013; Ikhsan, \& Rizal, 2014; Sugilar, 2013; Sumarmo et al., 2012).

\section{Soal nomor 4}

Ramli memesan bangku berkaki 3 dan meja berkaki 4 pada seorang tukang kayu. Bangku yang dipesan 4 buah lebih banyak dari banyak meja. Jumlah kaki bangku dan meja yang digunakan untuk memenuhi pesanan Ramli tersebut adalah 68 buah berapakah banyak bangku berkaki 3 dan meja berkaki 4 yang diperoleh Ramli?

\section{Jawaban siswa:}




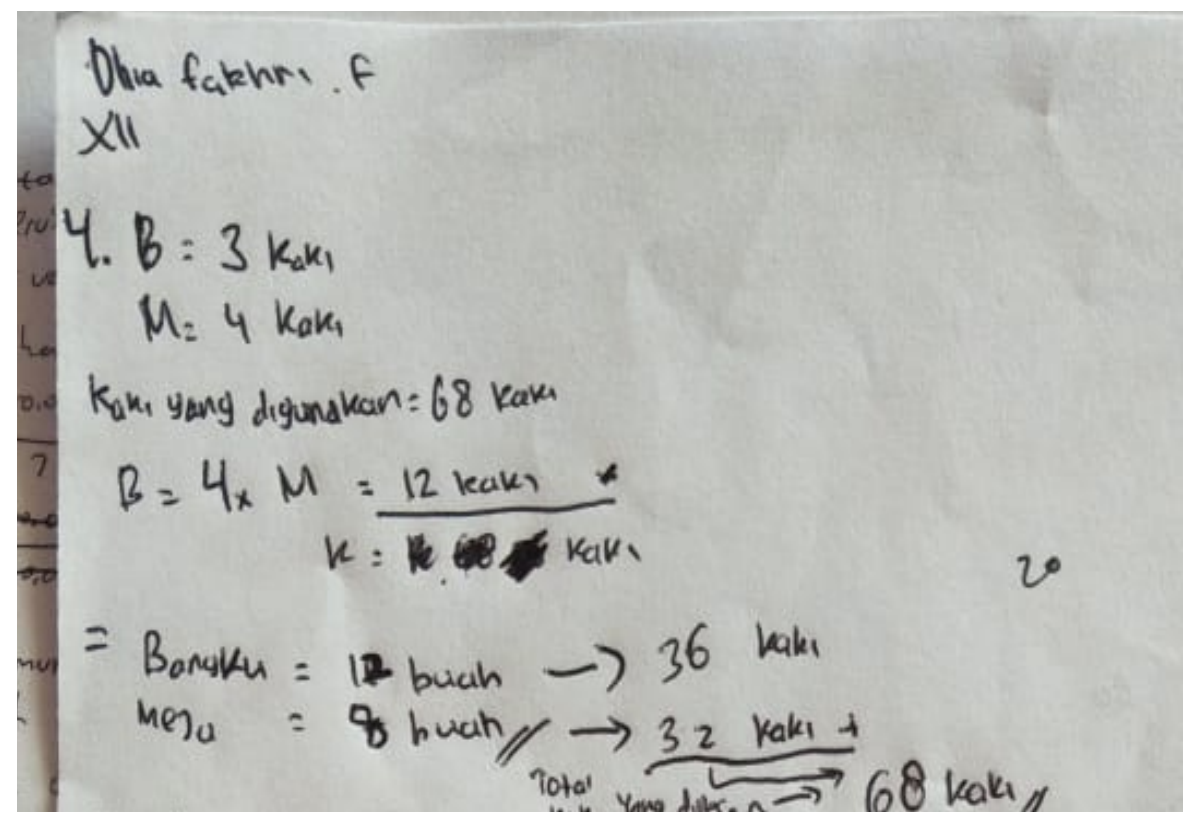

Gambar 3. Jawaban Siswa yang Berdisposisi Matematis Rendah

Pada Gambar 3 tampak bahwa siswa dengan disposisi matematis rendah saat mengerjakan soal nomor 4, ia tidak dapat memahami soal. Siswa tidak dapat merencanakan dan melakukan perhitungan sesuai rencana dengan tepat, tidak mampu melakukan pengecekan kembali pada hasil jawaban yang dibuat sehingga jawaban yang peroleh tidak tepat. Dengan demikian dapat disimpulkan bahwa siswa dengan disposisi matematis rendah $(\mathrm{R})$ tidak dapat memenuhi semua indikator kemampuan pemecahan masalah (Akbar et al., 2018; Choridah, 2013; Ikhsan, \& Rizal, 2014; Sugilar, 2013).

Dari data hasil belajar siswa di setiap tingkatan disposisi matematis dapat dinyatakan bahwa miskonsepsi indikator kemampuan pemecahan masalah siswa dengan tingkat disposisi matematis tinggi (T) dan sedang (S) terletak pada indikator memahami soal dan mengecek ulang hasil perhitungan. Sedangkan untuk miskonsepsi indikator kemampuan pemecahan masalah siswa dengan tingkat disposisi matematis rendah (R) terletak pada semua indikator kemampuan pemecahan masalah.

\section{SIMPULAN}

Berdasarkan hasil analisis data dengan uji statistik (Uji Anova-One Way) diperoleh bahwa hasil tes kemampuan pemecahan masalah siswa pada setiap tingkatan disposisi matematis memiliki nilai rata-rata yang berbeda, oleh karena itu peneliti mengidentifikasi pencapaian dan miskonsepsi siswa pada setiap indikator kemampuan pemecahan masalah. Dari kelima soal yang memuat indikator kemampuan pemecahan 
masalah matematis didapat bahwa soal nomor 2 adalah soal yang secara merata dapat dipecahkan oleh setiap tingkatan dispoisisi matematis siswa. Pada tingkat disposisi matematis tinggi $(\mathrm{T})$ siswa paling banyak menjawab dengan benar soal pertama, sedangkan pada tingkat disposisi matematis sedang (S) siswa paling banyak menjawab dengan benar soal nomor lima. Pada tingkat disposisi matematis rendah (R) siswa paling banyak menjawab soal dengan benar pada soal nomor lima. Miskonsepsi pada siswa dengan tingkat disposisi tinggi $(\mathrm{T})$ dan tingkat disposisi edang (S) terletak pada soal nomor 3 dengan miskonsepsi pada indikator memahami soal dan melakukan pengecekan kembali. Sedangkan pada siswa dengan tingkat disposisi matematis rendah (R) miskonsepsi terletak pada semua indikator kemampuan pemecahan masalah matematis.

\section{DAFTAR RUJUKAN}

Akbar, P., Hamid, A., Bernard, M., \& Sugandi, A. I. (2018). Analisis Kemampuan Pemecahan Masalah dan Disposisi Matematik Siswa Kelas XI SMA Putra Juang dalam Materi Peluang. Jurnal Cendekia: Jurnal Pendidikan Matematika, 2(1), 144-153.

Azwar, S. (2013). Penyususnan Skala Psikologi. Yogyakarta: Pustaka Belajar

Choridah, D. T. (2013). Peran pembelajaran berbasis masalah untuk meningkatkan kemampuan komunikasi dan berpikir kreatif serta disposisi matematis siswa SMA. Infinity Journal, 2(2), 194-202.

Haryono, A., \& Tanujaya, B. (2018). Profil Kemampuan Penalaran Induktif Matematika Mahasiswa Pendidikan Matematika UNIPA Ditinjau dari Gaya Belajar. Journal of Honai Math, 1(2), 127-138.

Hidayat, W., \& Sariningsih, R. (2018). Kemampuan Pemecahan Masalah Matematis Dan Adversity Quotient Siswa SMP melalui Pembelajaran Open Ended. JNPM (Jurnal Nasional Pendidikan Matematika), 2(1), 109-118.

Ikhsan, M., \& Rizal, S. (2014). Penerapan Model Pembelajaran Berbasis Masalah untuk Meningkatkan Kemampuan Berpikir Kritis dan Disposisi Matematis Siswa. Jurnal Didaktik Matematika, 1(1).

Rahmasantika, D., \& Prahmana, R. C. I. (2018). Analisis Kesalahan Siswa pada Operasi Hitung Pecahan Berdasarkan Tingkat Kecerdasan Siswa. Journal of Honai Math, 1(2), 81-92.

Sabandar, J. (2010). "Thinking Classrom dalam Pembelajaran Matematika di Sekolah". Dalam T. Hidayat (Eds.) Teori, Paradigma, Prinsip dan Pendidikan 
Pembelajaran MIPA dalam Konteks Indonesia. Bandung: FPMIPA UPI.

Sugilar, H. (2013). Meningkatkan Kemampuan Berpikir Kreatif dan Disposisi Matematik Siswa Madrasah Tsanawiyah Melalui Pembelajaran Generatif. Infinity Journal, 2(2), 156-168.

Sumarmo, U., Hidayat, W., Zukarnaen, R., Hamidah, M., \& Sariningsih, R. (2012). Kemampuan dan Disposisi Berpikir Logis, Kritis, dan Kreatif Matematik (Eksperimen terhadap Siswa SMA Menggunakan Pembelajaran Berbasis Masalah dan Strategi Think-Talk-Write). Jurnal Pengajaran MIPA, 17(1), 17-33.

Sumartini, T. S. (2018). Peningkatan Kemampuan Pemecahan Masalah Matematis Siswa Melalui Pembelajaran Berbasis Masalah. Mosharafa: Jurnal Pendidikan Matematika, 5(2), 148-158.

Wardanny, G. S. P. (2017). Kemampuan Pemecahan Masalah Matematis Ditinjau dari Disposisi Matematis Siswa SMPN 3 Kediri pada Materi Lingkaran Tahun Ajaran 2016/2017. Simki-Techsain 1(8). 